\title{
Bio-ecology and Management of Citrus psylla, Diaphorina citri Kuwayama on Citrus - A Review
}

\author{
Naveen Vikram Singh* and G.S. Yadav \\ Department of Entomology, CCSHAU, Hisar-125004, India \\ *Corresponding author
}

A B S T R A C T

\begin{tabular}{|l|}
\hline Ke y w o r d s \\
Cirtus psyllid, \\
Greening disease, \\
Bioecology and \\
Management
\end{tabular}

\section{Introduction}

The productivity and quality of citrus is severely affected by several factors; insect pests being one of them. Great diversity of soils and agro ecosystems in which citrus is grown in Asia are rich sources of insect fauna. In India 250 species of insects have been reported on various citrus species (Pruthi and Mani, 1945; Wadhi and Batra, 1964). A number of insect pests attack citrus plants both in the nurseries as well as in the orchards inflicting heavy economic losses. Majority of the insect pests occur at the new flush stage and damage the new growth thereby hampering the plant development. Among the insect pests, citrus psylla, Diaphorina citri
Kuwayama (Hemiptera: Psyllidae) is considered the most destructive pest causing heavy losses in citrus growing areasand the losses ranged from 83-95 per cent (Randhava, 1974). Both nymphs and adults of psylla suck the cell sap from flower buds, leaves and young shoots and result in leaf distortion, curling and complete defoliation or shedding of flower and leaves. This insect has become immensely important because it is the vector of the bacteria, Candidatus Liberibacter asiaticus that causes citrus greening disease that is restricted to the phloem vessels (Gravena, 2005). No control method will totally eliminate psyllids and the risk of pathogen transmission within a grove. Implementation of IPM practices to suppress 
the overall psyllid population will likely help slow the spread of the disease and maintain the economic feasibility of citrus production. Development of such a program requires knowledge of the biology of the pest, including factors that regulate psyllid populations, and available control options. The current review provides subsequent developments in knowledge of the biology, ecology, and management of $D$. citri.

\section{History and distribution}

The citrus psylla, Diaphorina citri Kuwayama is currently one of the most important insectpest and as a vector of destructive greening disease of the world citriculture. Tirtawidjaja et al., (1965) demonstrated that the veinphloem degeneration disease of Indonesia is transmitted by $D$. citri. Salibe and Cortez (1966) published preliminary evidence that $D$. citri is the vector of leaf mottling and this was later confirmed by Celina et al., (1966) and Martinez and Wallace (1967). It was first reported in 1907 from Taiwan and is now well distributed across several countries (Halbert and Manjunath, 2004). Capoor et al., (1967) have shown convincingly that $D$. citri is an efficient vector of greening disease of citrus in Indian continent and (Boykin et al., 2012) was first reported from the continental USA (Florida) in 1998 and now occurs from Florida to California. The geographical origin of $D$. citri is thought by some to be Southern Asia, probably India. Mead (1977) listed the Far East as the geographical origin of the psyllid. The Asian citrus psyllid is found throughout Asia, in the Saudi Arabian Peninsula and in some islands in the Indian Ocean. It is known to occur in China, India, Myanmar, Taiwan, Philippine Islands, Malaysia, Indonesia, Sri Lanka, Pakistan, Thailand, Nepal, Hong Kong, Ryukyu Islands, Afghanistan, Saudi Arabia, Réunion and Mauritius (Mead, 1977 and Halbert and Manjunath, 2004). The psyllid was known to be in Brazil (Mead, 1977) since the 1940s (Costa Lima, 1942). During the 1990s, D. citri invaded the West Indies, Abaco Island, Grand Ahama Island and Cayman Islands (Halbert and Nunez, 2004), and it was found in Florida during 1998 (Tsai and Liu, 2000). During 2001, the psyllid was found in the Dominican Republic, Cuba (Halbert, and Nunez 2004), Puerto Rico (Pluke et al., 2008) and Texas (French et al., 2001). It has recently been reported in many new areas in the Americas including Mexico, Venezuela and Argentina (Halbert and Nunez, 2004).

\section{Population dynamics of citrus psylla in relation to abiotic factors}

The climatic conditions in citrus growing areas are characterized by mild temperature and high humidity, which favors the pests and disease incidence. In the past few decades the growers are facing a high incidence of pest and also the citrus decline or dieback. Husain and Nath (1927) reported that peak period of psyllid infestation was almost synchronous with the flush of fresh shoots in India. They had further reported that the pest becomes active by the end of February and its population rapidly increases during March and April. The adults predominated during May and June and fresh colonies develop in July. It begins to disappear during the middle of October and occurs only in small numbers thereafter during December and January and seasonal incidence of $D$. citri on orange in some districts of Punjab and recorded maximum population during September and November, while decline in population was noted December-January (Singh and Singh, 1990). There were four peaks of pest population of D. citri on citrus which occurred during March, June-July, AugustSeptember and October-November (Atwal et al., 1970). Mild winter followed by a favorable spring provides suitable conditions for a high population build up. In Florida, 
populations of adult, $D$. citri in orange jasmine (M. paniculata) and potted grapefruit (C. paradise) were continually present with peak populations during June-July, September-October, December, and FebruaryApril (Tsai et al., 2002). Teck et al., (2011) found that $D$. citri population fluctuates throughout the year on citrus honey mandarin but nymphs were generally higher during the rainy season from October to January than during the dry season and adult and egg population peaks for a short period generally coincided with three annual flushing cycles in August-September, February-March and June-July between March 1998 and December 2000 in Sarawak.

Sahu and Mandal (1997) at Mohanpur, West Bengal observed that the pest remained active from the first week of June to the end of July, second week of September to the end of December, and from second week of February up to the end of April, during which the population of $D$. citri peaked 3 times (end of June, end of November and mid-April) on Citrus medica. Moderate climatic conditions coupled with the flushing of citrus trees favoured the development and activity of nymphs, while extremes of both high and low temperatures, low relative humidity and high rainfall were detrimental, whereas, Arora et al., (1997) at Abohar, India reported that psyllid remained active more or less throughout all three years of their study and there was a positive correlation between temperature and psyllid population and a negative correlation with relative humidity. In case of nymphal population, two peaks were observed, one during the second fortnight of March or first fortnight of April and the other during the first fortnight of September/October, which coincides with the occurrence of fresh vegetative flushes. Chavan and Summanwar (1993) reported that the population build-up of the pest was mainly related to the flushing rhythms of the plants. They also found maximum population on Mosambi sweet orange and citropsis (Citropsis schweinfurthii) in January and February, whereas the lowest population density occurred from July to October following monsoon rains. They also reported that life span of the psylla depends on the plant species on which it breeds. Similarly, Arora et al., (1997) obtained a positive correlation between temperature and psyllid population and a negative correlation with relative humidity. Survivorship of adults of Asian citrus psyllid was best at humidity above 53 per cent, but there was significant survival at humidity as low as 7 per cent (McFarland and Hoy, 2001). Gupta and Bhatia (2000) found that the pest population was active throughout the year except for December and January. The peak activity of nymphs was observed during March-April (45-50/shoot) whereas, the adults assumed peak during April (20-23/shoot). Further, Kalita and Baruah (2001) reported that the population of $D$. citri reached its peak in the month of May and the correlation study showed that the population of psylla exhibited significant positive correlation with the minimum temperature. In Brazil, it has been observed that psyllids were present throughout the year but had a low population levels in the autumn and winter and the highest population density during the end of spring season and the beginning of summer season (Yamamoto et al., 2001). Tsai et al., (2002) observed the highest population density of $D$. citri (2.1 psyllids/shoot) on orange jasmine in September, 1999, but the highest population density (1.5 psyllids/shoot) on grapefruit was in early July, 1999. The mean population densities on orange jasmine and grapefruit were 0.49 and 0.45 per shoot, respectively from June, 1999 to July, 2000.Viraktamath and Bhumannavar (2002) recorded peak population of $D$. citri during March-April and July-August. In temperate regions, mild winter followed by favourable 
spring provided a suitable condition for high population build up. During winter, heavy mortality of pest i.e., 53 per cent in July to 98 per cent in December occurred and the eggs fail to hatch, and 58 per cent of the hatched nymphs fail to develop into an adult. Survival studies conducted by Ashihara (2004) reported that the survival rates of 4-6 per cent of a population of $D$. citri in Kuchinotsu (northern Kyushu, Japan) following a winter with a minimum temperature of $-3.3^{\circ} \mathrm{C}$, but Mizuno et al., (2004) observed 63 and 100 per cent mortality of adults of $D$. citri following 2 and 4 days of exposure to $0^{\circ} \mathrm{C}$, respectively with no significant difference in mortality rates of males and females. Further, Shivankar and Rao (2005) observed that Diaphorina citri is more active in spring and after monsoon flushes but during winter and summer, however, thetemperature at $40^{\circ} \mathrm{C}$ was found detrimental to their population build up.

Moderate showers wash away the population. However, dry days witness rapid buildup of the pest. Heavy and prolonged flushing coupled with low temperature and high humidity favoured psylla outbreak. Nehru et al., (2006) found that heavy rainfall during August had an adverse effect on the population of $D$. citri resulting in a sharp decline in population. Temperature and relative humidity ranging from 24.77 to $32.49^{\circ} \mathrm{C}$ and 40.85 to 65.78 per cent, respectively, proved conducive for the development of the psyllid and there was a positive and significant correlation $(\mathrm{r}=0.876)$ between psyllid count and temperature. These two biotic factors jointly influenced the population buildup of $D$. citri to the extent of 79.4 per cent. Similar work conducted by Hall et al., (2008) recorded 26.5, 16.8 and 0.27 eggs, nymphs and adult/shoot, respectively on young grapefruit trees but on mature orange trees, 16.0, 12.7 and 0.31 eggs, nymphs, and adults/shoot were observed.
Population dynamics studies conducted by Sharma (2008) proved that the adult population of $D$. citri was very low during December and January but with the increase in temperature at the end of February, the activity of adults increased and the population of both adults and nymphs increased but significant increase in nymphal population was observed during March (41-47 nymphs). A decrease in nymphal population was recorded during May-June but attained the maximum infestation during July when the adult population was $92-111 / 25$ leaves. It was also observed that the nymphal population also remained quite high during August, when the weather factors, viz. minimum, maximum, mean temperature $\left({ }^{\circ} \mathrm{C}\right)$, relative humidity $(\%)$, the sunshine (hours) and rainfall $(\mathrm{mm})$, respectively ranged from 26.0-27.2, 33.5$34.9,30.4^{\circ} \mathrm{C}, 74-84$ per cent, 6.3 to 9.3 hours and 24.5 to $297.7 \mathrm{~mm}$. The correlations between population (mixed, nymphs and adults) of citrus psylla and different abiotic factors revealed that minimum, maximum and mean temperatures, relative humidity and vapour pressure had a positive relation with both nymphal and adult population whereas wind velocity had very low impact on adults. Further, Beattie and Barkley (2009) reported that $D$. citriis better adapted to regions with high saturation deficits (high temperatures and low relative humidity levels) than to regions with low saturation deficits (medium to high temperatures and high relative humidity levels). However, reduced oviposition by $D$. citri has been reported at relative humidity levels below 40 per cent (Skelley and Hoy 2004). Teck et al., (2011) found that psyllid population levels are positively related to the availability of new shoot flushes. Psyllid populations are adversely affected by weather conditions and parasitoids. Adult psyllid populations increased exponentially during periods of flush growth and migration and dispersal of the adults was also related to flushing cycles. 
Dispersal and colonisation of new trees are greatest in September-October, at the onset of the rainy season. Studies conducted by Rakhshani and Saeedifar (2013) reported that the nymph population peaks in three periods (beginning of March, end of August and end of January) and moderate climatic conditions coupled with the flushing of citrus tree are two main factors for an increase of the development and activity of nymphs resulting in pest population increase while, extreme of both high and low temp., low relative humidity and high rainfall were detrimental. Four coccinellids, one syrphid, two parasitoid and two spiders were intent as natural enemies of the psyllid. Devi and Sharma (2014) found that the population of D. citri was present throughout the year but only adults found surviving during December and February. There was no nymphal population when the maximum temperature was $>39^{\circ} \mathrm{C}$ or $<7^{\circ} \mathrm{C}$. Two population peaks of nymphs were observed, first in April-May and second in August-September. Thereafter, there was abrupt decline in nymphal population during June and July during both the years when the weather conditions i.e., maximum, minimum temperature $\left({ }^{\circ} \mathrm{C}\right)$, relative humidity $(\%)$, rainfall (mm.) and the sunshine (hrs.) ranged from 24.4-44, 22.4-31.8, 25.5-100, 0-108.0 and $0-13.5$, respectively. Highest peaks of an adult were found during May followed by June. With the decrease in temperature from the end of September, the population of $D$. citri started to decrease and reached its lowest during the winter season. Correlation analysis for both the years indicated that maximum and minimum temperature, sunshine and rainfall were positively correlated with nymphal, adult and mixed population but the effect of rainfall on adult population was nonsignificant, while relative humidity was negatively correlated. Population studies conducted by Sule and Muhamad (2014) reported a high number of adult $D$. citriin upper canopy, north cardinal point and leaves growth stage 1. The adult and immatures found on $C$. suhuinensis on all sampling dates, except in the months of December 2011 and January and May 2012, for immature. The peak population of $D$. citri adults were found in months of March and June in both years, while in immature peak populations were identified in the months of July 2011 and March 2012. Correlation analysis of $D$. citri adults and immature with flush growth leaves and weather parameters shows adult $D$. citri population to correlate with a number of flush leaves $(r=0.93)$ and temperature $(r=$ 0.45 ), whereas, immature $D$. citri population only correlated with flush leaves. Jayanthimala et al., (2015) study the role of biotic and abiotic factors in relation to citrus psylla incidence on mandarin (Citrus reticulata). The citrus psylla population was recorded high if minimum temperature ranged between $18.71-19.42^{\circ} \mathrm{C}$, the maximum temperature ranged between $30.57-32.28^{\circ} \mathrm{C}$ and Max. Relative humidity is $87.1-95.6 \%$. If minimum temperature ranged between 19.5$29.33^{\circ} \mathrm{C}$ with minimum relative humidity 64.6-81.0\% then psylla population was high. The correlation analysis with weather parameters showed positive significant correlation with maximum temperature $(\mathrm{r}=$ $0.23)$ at $P<.01$ level and negative significant correlation with minimum temperature $(\mathrm{r}=-$ $0.21)$ and rainfall $(\mathrm{r}=-0.18)$ at $P<0.05$ level. Lakra et al., (1983) demonstrated the key mortality factors for nymphs of $D$. citri as low relative humidity $(<40 \%)$ during May-June and low temperature below $5^{\circ} \mathrm{C}$ during December-February. The most favourable conditions for population build-up were a gradual rise in daily minimum and maximum temperatures from late February to early May under dry conditions with relative humidity ranging from 30 to 75 per cent. Whereas Atwal et al., (1970) observed that extremes of both high and low temperatures, however, were injurious to citrus psylla in Punjab. Exposure to $-3^{\circ} \mathrm{C}$ for 1 hour was lethal for 
nymphs and exposure to $-10^{\circ} \mathrm{C}$ was lethal for adults (Xu et al., 1994). Working on population Wankhade et al., (2015) observed that the peak nymphal population of citrus psylla in the month of February-March and August-September and it was low in MayJune and December. The reduction in the pest coincided with a reduction in new flushes during April to June months and decreased with a low temperature in November and December months and increased in temperature from May to June month.

\section{Biology of citrus psylla}

Many workers studied the biology of $D$. citri in India (Hussain and Nath, 1927; Pruthi and Mani, 1945; Mangat, 1966; Atwal, 1962 and Singh, 1963) and Philippines (Catling, 1970). Working on nymphal instars, Hussain and Nath (1927) gave a detailed description of all the five nymphal instars. The nymphs are orange yellow, flattened and circular in shape. They remain congregated close to the site of oviposition and for few days feed there. Subsequently, they move to older parts like matured leaves, thick shoot, petioles etc. The nymph cast skin five times (Atwal, 1962) and become adult in 12 to 25 days (Pruthi, 1969) or 8-60 days (Viraktamath and Bhumannavar, 2002). Morphological studies conducted by Bindra (1969) observed almond-shaped yellow eggs laid during day time either singly or in clusters or in groups of double and triple straight lines deep into the tender plant tissue with the help of strongly pointed ovipositor and were anchored there by means of a short stalk embedded in the plant tissue. Pande (1971) Studied the biology of Diaphorina citri, Pairing started soon after emergence. Fecundity was 180-520 eggs/female. The incubation period lasted for 4-18 days. There were five nymphal instars, which took 10-30 days. The adults were long-lived. The complete life-cycle took $14-48$ days. Ten overlapping generations were detailed in a year. The insect was most active during March-April. Aubert and Quilici (1988) reported a sex ratio of 49 per cent males to 51 per cent females. Females continuously lay eggs throughout their lives if young leaves are present. Adult females have been observed during their lifetime to lay 500 to 800 or more eggs over a period of two months with a maximum of 1900 (Nava et al., 2007). Dharajothi et al., (1989) studied the spatial distribution of $D$. citri in the greenhouse and in the field eggs and nymphs follow a contagious distribution, whereas the adults show random to aggregated distribution. The mean population density of different stages of the insect among the four directions (north, east, south and west) of a tree canopy does not vary significantly. Khan et al., (1989) studied the biology of the citrus aphalarid, $D$. citri on an alternative food plant in the laboratory; adults reached sexual maturity 2-6 days after emergence. Oviposition took place (singly or in clusters on all the tender parts of the plant) immediately after mating up to 350 eggs were laid by a female in 14 days. The egg stage lasted 2-11 days and the nymphal stage (5 instars) 12-x22 days. Adults lived for 14 days and there were 9 overlapping generations in a year. Similarly, Chavan and Summanwar (1993) observed that females laid eggs in feather flush. The eggs measure $0.3 \mathrm{~mm}$ in length and $0.13 \mathrm{~mm}$ in width with $0.038 \mathrm{~mm}$ long stalk (Hussain and Nath 1927). Around Ludhiana, eggs hatch in 3-4 days (April-October), 5-6 days (November and March), 7 days (February) and 11-12 days (December-January) (Mangat, 1966) depending on the time of the year. Just before hatching red coloured eyespots become visible through the eggshell. The nymphs took 6 to 9 minutes to emerge from the egg.

Working in China, Xu et al., (1994) reared D. citri on caged citrus and Murraya paniculata plants. They found that it completed 6-7 generations on citrus and 9-11 generations on 
M. paniculata annually in the Fuzhou area in Fujian, China. Average adult lifespan was 3040 days and each generation lasted 18-59 days in spring and autumn. Overwintering adults had a lifespan of 260 days. In India, Chakravarthi et al., (1998) studied the biology of Diaphorina citri on three different hosts viz. acid lime, sathgudi, sweet orange and curry leaf. Among the three-host curry leaf was the most preferable host with a high rate of fecundity and short duration of the life cycle. Liu and Tsai (2000) reported the lowtemperature developmental thresholds for $1^{\text {st }}$ through $5^{\text {th }}$ instars were estimated at $11.7^{\circ} \mathrm{C}$, $10.7^{\circ} \mathrm{C}, \quad 10.1^{\circ} \mathrm{C}, \quad 10.5^{\circ} \mathrm{C}$ and $10.9^{\circ} \mathrm{C}$, respectively. The mean longevity of females increased with decreasing temperature within $15-30^{\circ} \mathrm{C}$. The maximal longevity of individual females was recorded $117,60,56,52$ and 51 days at $15^{\circ} \mathrm{C}, 20^{\circ} \mathrm{C}, 25^{\circ} \mathrm{C}, 28^{\circ} \mathrm{C}$ and $30^{\circ} \mathrm{C}$, respectively. The average number of eggs produced per female significantly increased with increasing temperature and reached a maximum of 748.3 eggs at $28^{\circ} \mathrm{C}$. The population reared at $28^{\circ} \mathrm{C}$ had the highest intrinsic rate (0.199) and net reproductive rate (292.2), and the shortest population doubling time (3.5 days) and mean generation time (28.6 days) compared with populations. Further, Tsai and Lui (2000) reported that survival of immature on orange jasmine, grapefruit, rough lemon and sour orange was $75.4,84.6,78.3$ and 68.6 per cent, respectively. Female adults lived for 39.7, 39.7, 47.6 and 43.7 days respectively, on these host plants. The average number of eggs laid per female on grapefruit (858 eggs) was significantly more than those on other hosts. The mean population generation time on these hosts ranged from 31.6 to 34.1 days. Skelley and Hoy (2004) studied that adult of D. citri ceased laying eggs when rearing temperatures reached $34^{\circ} \mathrm{C}$ for five days; once temperatures were reduced, the adults gradually began laying eggs again over 2-3 weeks. Psyllid produced fewer eggs when relative humidity dropped below 40 per cent. Adults may live several months and the females lay as many as 800 eggs in a lifetime (Mead, 1997). Nakata (2006) reported that nymphs of citrus psylla fail to develop to adults at $15.0^{\circ} \mathrm{C}$ and the mortality increased at $32.5^{\circ} \mathrm{C}$. The incubation period decreased at a higher temperature, varying from 15.0 to 2.5 days. These nymphs became adults in 36.3 days at $15.0^{\circ} \mathrm{C}$ and in 10.7 days at $30^{\circ} \mathrm{C}$, but 16.8 days at $32.5^{\circ} \mathrm{C}$. Nehru et al., (2006) found that the incubation period of eggs of $D$. citri on Citrus sinensis cv. Jaffa ranged from 3.018.49 days during different generations. It passed through 5 nymphal instars. The total nymphal period varied from 9.14 to 25.05 days. The pre-copulation, pre-oviposition and oviposition periods varied from 2.09 to 7.26 , 1.38 to 3.90 and 10.00 to 38.38 days, respectively. The respective adult longevity in male and female ranged from 10.41 to 74.00 and 13.77 to 80.22 days.

Fung and Chen (2006) were used to generalise developmental times from egg to adult at different temperatures. New adults reach reproductive maturity within 2 or 3 days, and oviposition begins about 1 or 2 days after mating (Wenninger and Hall, 2007). The mean population generation time at $25^{\circ} \mathrm{C}$ was, therefore, ranged from 20-22 days. Chhetry et al., (2012) observed that there were five nymphal stages with length varying from 0.26 $-2.96 \mathrm{~mm}$. The incubation, nymphal and adult longevity were $2.28 \pm 0.18,14.86 \pm 1.07$ and $10 \pm 1.23$ days, respectively. Thus, the psyllid has a total life cycle of 20-36.5 days (27.14 \pm 2.34 days) in laboratory conditions. Devi and Sharma (2013) reported that the number of eggs laid per female on kinnow $(683 \pm 86.11)$ and rough lemon (672 \pm 83.47) was significantly more than on curry leaf (616 \pm 65.85) and incubation periods varied from 3-4 day and no significant difference of nymphal development periods on all host plant. The average female longevity on a rough lemon 
(43 days) was significantly higher than kinnow (42.2 days) and curry leaf (39.7 days). There could be 6-16 generations in a year depending on prevailing weather conditions. Diaphorina citri is known to infest host plants other than citrus like curry leaf (M. koenigii) and it is the most preferred host with high rate of fecundity and short duration of life cycle. The pest completes $9-10$ or even upto 16 overlapping generations in a year (Hussain and Nath 1927 and Khan et al., 1989).

\section{Chemical control}

Several insecticides like monocrotophos, dimethoate, aldicarb, quinalphos, fenvalerate, fenthion, phosalone, oxydemeton methyl, diazinon, phosphamidon, malathion, fenitrothion, acephate, carbaryl and endosulfan were found quite effective against psylla (Radke et al., 1981; Buitendag, 1988; Tandon, 1992). The systemic neonicotinoid insecticide Imidacloprid (Admire), was applied to grapefruit, Citrus paradisi trees to determine its effects in the control of Asian citrus psyllid, D. citri. Significant positive correlations were obtained between imidacloprid titers in leaf tissue and the percentage of control levels achieved (Setamou et al., 2010). Dahiya et al., (1994) proved that insecticides like dimethoate (0.05\%), monocrotophos (0.05\%), phosphamidon $(0.05 \%), \quad$ decamethrin $(0.002 \%)$ and fenvalerate $(0.006 \%)$ gave better control of citrus psylla cypermethrin $(0.006 \%)$, chlorpyriphos $(0.05 \%)$, dichlorvos $(0.05 \%)$, endosulfan $(0.05 \%)$, malathion $(0.05 \%)$ and quinalphos $(0.05 \%)$. Ahmed et al., (2004) at Sarghoda, Pakistan found that methamidophos $(500 \mathrm{ml} /$ acre$)$, dimethoate (300 ml/ acre) and imidacloprid (250 g /acre) had almost equal effect on the population reduction of $D$. citri infesting Feuterell's early, Kinnow and musambi. All insecticides resulted in $90 \%$ reduction up to 7 days after spraying. Arora et al., (2005) reported that a pooled analysis over three years data revealed that two days after application, quinalphos $(0.075 \%)$ gave highest reduction $96.58 \%$ in nymphal population of citrus psylla. This was comparable to imidacloprid $(0.08 \%)$ treatment recording $95.12 \%$ nymphal mortality. Seven days post application, imidacloprid $(0.08 \%)$ was found to be superior followed by quinalphos $(0.075$ and $0.05 \%)$. Parallel results were obtained ten days after spraying also. The most effective treatment was imidacloprid $\quad(0.08 \%)$ causing $95.33 \%$ reduction in nymphal population, but it was at par with quinalphos $(0.075 \%)$, quinalphos $(0.05 \%)$ and triazophos $(0.075 \%)$. Data reveled that quinalphos $(0.05 \%)$ was most effective treatment for the control of citrus psylla. Further, Childers and Rogers (2005) revealed that treatment of systemic insecticide, imidacloprid had significantly lower adult population 5 DAT while aldicarb did not. However, both systemic insecticides provided the longest residual control of nymphs after 19 DAT. The insecticides spinosad and acetamiprid were ineffective in reducing adult population. The insecticides thiamethoxam, fenpropathrin and chlorpyriphos provided a significant reduction in adults. Dadmal et al., (2002) at Akola, Maharashtra tested different plant products \& chemical insecticides and found that acephate @ $0.05 \%$ was the most effective against $D$. citri. It controlled 97.59 and $98.95 \%$ nymphs of citrus psylla at 3 and 7 days after spraying (DAS), while azadirachtin (1500 ppm) gave $78.53 \%$ and $82.92 \%$ nymphal mortality at 3 and 7 DAS. Farmanullah et al., (2005) observed that the overall mean population was lowest 3.63 and 2.65 adults per six inches tender shoots in thiamethoxam $25 \mathrm{WG}$ treated plants after 1st and 2nd application, respectively, however, per cent decrease of psylla population in comparison to control after the first and second spray was also highest (72.20 and 83.54) in thiamethoxam $25 \mathrm{WG}$ as compared to other insecticides. 
Powell et al., (2007) evaluated the number of psyllids, per cent trees infested and the percentage of flush infested per tree was recorded over a 3-yearperiod. The plot was treated with 7 insect control treatments: Admire (imidacloprid) applied at12, 6, 3, or 2-month intervals; Temik and Meta-systox R applied annually, orinsecticide control using a randomised complete block design. Annual applications of Temik, Meta-Systox R, or Admire did not reduce psyllid populations. Biannual or more frequent applications of Admire significantly reduced psyllid numbers, the percentage of trees with psyllid infestations, and the percentage of flushes infested with psyllids. The data on bioefficacy of different insecticides indicated that except dimethoate $(0.05 \%)$ with 69.7 per cent nymphal mortality after 12 days of spray all other insecticides namely dimethoate $(0.075 \%)$, oxy demeton methyl $(0.075 \%)$, imidacloprid $(0.008 \%)$, chlorpyriphos $(0.1 \%)$, triazophos $(0.1 \%)$, thiamethoxam $(0.008 \%)$ and quinalphos $(0.075 \%)$ had significantly high (91-100\%) nymphal reduction of $D$. citri compared to either 3 or 7 days data (Sharma, 2008). Boina et al., (2009) concluded that feeding by psylla adults and nymphs on citrus plants treated daily with a sublethal concentration $(0.1 \mathrm{microgm} / \mathrm{L})$ of imidacloprid significantly decreased ( 8 days), fecundity $(33 \%)$ and fertility $(6 \%)$ as well as nymph survival $(12 \%)$ developmental rate compared with untreated controls. The magnitude of these negative effects was directly related to exposure duration and concentration. Furthermore, psylla adults that fed on citrus leaves treated systemically with lethal and sublethal concentrations of imidacloprid excreted significantly less honeydew compared with controls in a concentrationdependent manner suggesting the antifeedant activity of imidacloprid. The effect of seven insecticides from different groups viz. dimethoate, acetamiprid, flufenoxuron, fuzalon + teflubenzuron, thiamethoxam, pyriproxyfen and oil showed that all tested insecticides had a good effect on the pest during spraying time gradually the effect of contact insecticides decreased as such their effect compared to become significant. In this study thiamethoxam, dimethoate and acetamiprid showed the maximumper cent of mortality (97.7, 83.2 and 82.7\%, respectively). The least per cent of mortality $(18.7 \%)$ was obtained by using the oil, 21d after treatment (Abbaszadeh et al., 2011). Arora and Sharma (2011) studied the bioefficacy of some neonicotinoids, viz., acetamiprid, imidacloprid and thiamethoxam @ 0.004, 0.006, 0.008 and 0.01\% against citrus psylla, D. citri was evaluated. The results indicated that up to 7 days after spraying, imidacloprid $(0.01 \%)$ showed the highest reduction in the nymphal population of citrus psylla but it was found to best statistically on par with thiamethoxam @ $0.01 \%$ and thiamethoxam @ 0.008\%. Ten days after spraying thiamethoxam @ 0.01 and 0.008 per cent was found equally effective against citrus psylla. It is concluded that imidacloprid was very effective for initial knockdown of citrus psylla upto seven days after treatment whereas thiamethoxam had a greater residual effect as compared to imidacloprid and acetamiprid. Acetamiprid was found to be less effective compared to thiamethoxam and imidacloprid. Rao and Shivankar (2011) reported the toxicity of biorational insecticides viz. spinosad, abamectin, novaluron, sweet flag (Acorus calamus L.), petroleum spray oil, neem (Azadirachta indica) oil, azadirachtin, Bacillus thuringiensis, Verticillium lecanii and dimethoate (as standard) against the second instar nymphs of citrus psylla 2006. Based on LC50 values, spinosad, abamectin and novaluron were 9.93, 3.29 and 2.71 times more toxic to psylla nymphs than dimethoate. Further, field appraisal of these bio-rational insecticides along with neem soap and Pongamia (Pongamia glabra Vent.) soap 
against citrus psylla in 10-year-old acid lime (Citrus aurantifolia) cv. Pramalini showed that abamectin @ 0.38ml/L (90.2-92.5\% reduction) followed by petroleum spray oil @ $5.9 \mathrm{ml} / 1$ (89.8-90.4\% reduction) novaluron@ $0.55 \mathrm{ml} / 1 \quad(87.6-88.1 \%$ reduction) and spinosad @ 0.15 ml/1(65.5-72.3\% reduction) were found effective against citrus psylla for a period of 15 days.

Sarada et al., (2014) reported that the treatments were imposed during peak pest infestation period (December-March). All the treatments recorded low ACP population then control irrespective of the year and days after treatment. However, during both the years, novaluron10EC $(0.005 \%)$ recorded highest $(80 \%)$ pest control at 7DAS. This was on par with azadirachtin $(1 \%)$ and dimethoate30EC (0.06\%, standard check). At 14DAS also the same chemicals have shown superior performance with $>70 \%$ pest control. The effectiveness of the insecticides was in the order of novaluron> azadirachtin> dimethoate> Verticillium lecanii > neem oil > abamectin. Dalvaniya et al., (2015) reported that among the treatments, imidacloprid 17.8 SL@ $3.0 \mathrm{ml} / 10$ liters water was most effective with minimum population of $D$. citriat 1, 3, 7 and 10 days after spray, followed by diafenthiuron 50 EC @ 4.0 ml/10 litres water and thiamethoxam 25 WDG @ $3.20 \mathrm{~g} / 10$ liters water. Quasim and Hussain (2015) revealed that the efficacy of insecticides against citrus psylla, and mortality was observed after three days, seven days and then after one month. Four insecticides, Polytrin-C, Talstar, bifenthrin and imidacloprid applied, had an almost equal effect on the population reduction of citrus psylla on all citrus plants. Three days of spray showed a control of $96.91 \%, 94.33 \%, 93.83 \%$ and $93.06 \%$ following insecticides Polytrin C, imidacloprid, bifenthrin and Actara, respectively, calculated by Minitab 15. Psylla adults were exposed to different concentrations (500, 400, 300, 200 and 100 ppm) imidacloprid and bifenthrin, and two controlled conditions (with leaves and without leaves). Both imidacloprid and bifenthrin insecticides proved to be the most effective against $D$. citri with lethal times $\left(\mathrm{LT}_{50}\right)$ of 4 and 5 hours, respectively, at a concentration of $500 \mathrm{ppm}$, calculated from probability test with Minitab-15. Wankhade et al., (2015) evaluated against citrus psylla, the treatment with abamectin 1.9 EC @ 0.4 ml/l (0.0007\%) was found most effective in recording the least nymphal population of citrus psylla at $3^{\text {rd }}, 7^{\text {th }}$ and $14^{\text {th }}$ days after sprays over rest of the treatments. The next best treatment was imidacloprid 17.8 SL @ $0.25 \mathrm{ml} / 1$ (0.004\%). Dimethoate $(0.06 \%)$ recorded 18.18, 13.94 and 9.35 population of citrus psylla nymphs at $3^{\text {rd }}, 7^{\text {th }}$ and $14^{\text {th }}$ days after sprays, whereas, bio-rationals i.e., V. lecanii and B. bassiana recorded 33.97, 22.13, 17.97 and 39.00, $33.18,28.32$ respectively at $3^{\text {rd }}, 7^{\text {th }}$ and $14^{\text {th }}$ days after sprays.

\section{Biological control of citrus psylla}

Biological control should be encouraging where the insects are beyond the reach of chemical control. Therefore, the extent of their impact in Haryana requires further investigation. In addition to parasitism and host feeding by citrus psyllid parasitoids, the primary sources of psylla mortality in the field are naturally occurring generalist predators such as ladybird beetles, syrphid flies lacewings, and predatory mites (Michaud and Olsen, 2004; Michaud, 2004; Qureshi and Stansly, 2009; Juan-Blasco et al., 2012; Kistner et al., 2016). Yang et al., (2006) reported that $D$. citriin China was attacked by lacewings, Chrysopa boninensis Okamoto and Coccinella septempunctata Linnaeus, praying mantids, the whirligig mite and ants. Ants probably predate on immature $D$. citri in Florida (Michaud, 2002). Diaphorina citri has been found to be attacked by Coccinellids in 
Brazil (Gravena et al., 1996), syrphid flies in the genus Allograpta in Reunion and Nepal (Aubert 1987), and (Allograpta oblique Say) in Florida (Michaud 2002). In India, lady beetles like $C$. septempunctata, $C$. rependa, Cheilomenes sexmaculata, Chilocorus nigrita and Brumus suturalis (Fabricius) attacked $D$. citri (Husain and Nath 1927 and Batra et al., 1990). Van den Berg et al., (1992) reported eighteen species of spiders preying on $T$. erytreae, predominantly belonging to family Salticidae but the most abundant spider was $H$. velox, a species known to develop successfully on nymphs of citrus psylla. In region of Jammu, Bhagat and Nehru (1999) observed the Lady bird beetle, Coelophora saugeti and green lacewing, Chrysoperla carnea potential natural enemies of citrus psylla. And Gupta and Bhatia (2000) reported that four species of predatory coccinellids, viz. Leis dimidiate (Fabricius), $M$. sexmaculatus, Micraspis cardoni Timberlake and $C$. septempunctata, and a chrysopid predator were observed feeding on nymphs during the spring season. Singh (2017) observed that the two predatory beetles namely Coocinella Septempunctat (Linneaus) and cheilomenes sexmaculata (Febricus) in sweet orange field in agro climatic condition of Haryana.

The extent of control provided by each individual taxa remains largely unknown, though coccinellids seem to provide the citrus psylla control in Florida (Michaud, 2004; Qureshi and Stansly, 2007), a situation not seen in southern California. Work from Pakistan strongly suggests spiders are not important predators in unsprayed citrus orchards (Vetter et al., 2013). Tamarixia radiata, an ectoparasitoid, is a native to India (Chien, 1995) and plays an important role in biological control of $D$. citri than predators (Husain and Nath, 1927). Female of $T$. radiata attacks $D$. citri during 3rd, 4th or 5th instar of nymphal development (McFarland and Hoy, 2001 and Skelley and Hoy 2004). Tamarixia radiata is a host-specific, ectoparasitoid of Diaphorina citri nymphs, originally described from specimens that emerged from parasitized nymphs on lemon leaves collected from Pakistan (Waterston, 1922). In Taiwan, T. radiata had higher population than $D$. aligarphensis during parts of the years (Cheu et al., 1987). In China (Yang et al., 2006) reported that 36 per cent parasitism rate was observed on new branches in the summer, and 46 per cent on branches in the autumn and negative relationship between the parasitism rate (per cent between parasitized and total nymphs) and the percentage of branches with $D$. citri nymphs, but there was no relationship between the nymphal parasitism rate and the percentage of branches infested with adult (Paiva and Parra, 2012).

\section{References}

Abbaszadeh, G., Ameri, A., Torabizadeh, M. 2011.Evaluation of different groups of insecticides on Asian citrus Psylla, Diaphorina citri K. (Homoptera: Psyllidae). Pesticide Research Journal, 23(1): 52-54.

Arora, P.K. and Sharma, D.R. 2011. Bioefficacy of some neonicotinoids against citrus psylla, Diaphorina citri Kuwayama on kinnow mandarin. Journal of Insect Science, 24(4): 399401.

Arora, P.K., Battu, R.S. and Singh, B. 2005. Bioefficacy of some insecticides against citrus psylla viz-a-viz determination of quinalphos residues in kinnow mandarin fruits. Pest Management in Horticultural Ecosystem, 11(1): 33-38.

Arora, P.K., Thind, S.K. and Nirmaljit, K., Grewal, I.S. and Kaur, N. 1997. Population dynamics of citrus psylla, Diaphorina citri Kuwayama on Kinnow mandarin in relation to temperature and 
relative humidity. Indian Journal of Ecology, 24(2): 179-183.

Ashihara, W. 2004. Survival of Asian citrus psyllid, Diaphorina citri Kuwayama adults under winter temperature conditions in central and south Kyushu. Japanese Journal of Applied Entomology and Zoology, 48: 207-211.

Atwal, A. S. 1962. Biology and control of citrus psylla, Diaphorina citri Kuw. (Hemi; Psyllidae). Punjab Horticultural Journal 2: 104-08.

Atwal, A. S., Chaudhary, J. P. and Ramzan, M. R. 1970. Studies on the development and field population of citrus psylla, Diaphorina citri Kuwayama (Psyllidae: Homoptera). Research journal of Punjab Agriculture University, 7: 33338.

Aubert B. 1987. Trioza erytreae del Guercio and Diaphorina citri Kuwayama (Homoptera: Psyllidae), the two vectors of citrus greening disease: Biological aspects and possible control strategies. Fruits, 42: 149-62.

Aubert, B. and Quilici, S. 1988. Monitoring adult psylla on yellow traps in Reunion Island. In: Garnsey, S. M., Timmer, L. W. and Dodds, J. A. (eds.), Proceedings of the $10^{\text {th }}$ Conference of International Organization of Citrus Virologists. International Organization of Citrus Virologists, Riverside, CA, pp. 249254.

Batra, R. C., Sharma, D. R., Singh, R. and Singh, S. N. 1990. Status of citrus insect pests and their enemies in different agro-climatic zones of Punjab. Indian Journal of Horticulture, 47: 331-36.

Beattie, G.A.C. and Barkley, P. 2009. Huanglongbing and its vectors. A pest specific contingency plan for the citrus and nursery and garden industries (Version 2), 272 Horticulture Australia. http://handle.uws.edu.au:8081/1959.7/u ws:31219.
Bhagat, K. S. and Nehru, R.K. 1999. Sap feeding pests of citrus in Jammu. In: Int. Symp. Citriculture at N.R.C. for Citrus, Abstracts, Nagpur, pp 130.

Bindra, O.S. 1969. In: review of work done, lacunae in our knowledge and future lines of work ICAR workshop, fruit research, Punjab Agriculture University, Ludhiana. April. pp. 28-30.

Boina, D.R., Onagbola, E.O., Salyani, M. and Stelinski, L.L. 2009. Antifeedant and sub lethal effects of imidacloprid on Asian citrus psyllid, Diaphorina citri. Pest Management Science, 65(8):870877.

Boykin L. M., Barro P. De, Hall D. G., Hunter W. B., McKenzie C. L., Powell C. A. and Shatters R. G. 2012. Overview of worldwide diversity of Diaphorina citri Kuwayama mitochondrial cytochrome oxidase 1 haplotypes: two Old World lineages and a New World invasion. Bulletin of Entomological Research, 102: 573-82.

Buitendag, C.H. 1988. Citrus Greening Disease. Citrus and Subtropical Fruit Journal, 640:6-7.

Capoor, S.P., Rao, D.G. and Viswanath, S.M. 1967. Diaphorina citri Kuwayama, a vector of the greening disease of citrus in India. Indian Journal of agricultural Science, 37:572-576.

Catling, H. D 1970. The bionomics of the South African citrus psylla, Trioza erytreae (Del Guercio) (Homoptera: Psyllidae). 4. The influence of predators. Journal of Entomological Society of South Africa, 33: 341-48.

Celina, C.S., Salibe, A.A. and Cortez R.E. 1966. Diaphorina citri Kuwayama, the insect vector of the leaf mottling virus of citrus in Philippines. unpublished report.

Chakravarthi, V.P., Savithri, P., Prasad, P.R. and Rao, N.V. 1998. Biology and seasonal abundance of citrus psylla, 
Diaphorina citri Kuwayama. Advances in IPM for horticultural crops. Proceeding of the first National Symposium on Pest Management in Horticultural Crops: environmental implications and thrust, Banglore, India, $26-29$.

Chavan, V.M. and Summanwar, A.S. 1993. Population dynamics and aspects of the biology of citrus psylla, Diaphorina citri Kuw. in Maharashtra. pp. 286-290 In P. Moreno, J. V. da Graça, and L. W. Timmer [eds.], Proc. 12th Conference of the International Organization of Citrus Virologists. University of California, Riverside.

Chien, C. C. 1995 . The role of parasitoids in the pest management of citrus psyllid. In: pp. 245-61. Proc Symp Res Develop Citrus Taiwan, Taichung, Taiwan.

Childers, C.C. and Rogers, M.E. 2005. Chemical control and management approaches of the Asian citrus psyllid, Diaphorina citriKuwayama in Florida citrus. Proceedings of Florida. State Horticultural Society, 118: 49-53.

Costa Lima A M da. 1942. Homopteros. Insetos do Brazil 3: 1-327 (Original not seen).

Dadmal, S. M.; Pawar, N. P.; Kale, K. B. and Shivankar, S. K. (2002). Efficacy of plant products and some insecticides against citrus psylla, Diaphorina citri Kuwayama. Insect Environment, 8 (2): 94-95.

Dahiya, K.K., Lakra, R.K., Dahiya, A.S. and Singh, S.P. 1994. Bioefficacy of some insecticides against citrus psylla ( $D$. citri Kuw.) (Psyllidae: Hemiptera). Crop Research, 8:137-140.

Dalvaniya D.G., Patel, P.S., Pareek, A. and Panickar, B. 2015. Efficacy of some insecticides against citrus psylla, Diaphorina citri Kuwayama on kagzi lime. Journal of Entomological Research, 39(2): 141-144.
Devi, H.S. and Sharma, D.R. 2013. Comparative biology of citrus psylla Diaphorina citri Kuwayama on three host plants during spring season. Journal of Insect Science, 26 (1): 121125.

Devi, H.S. and Sharma, D.R. 2014. Impact of abiotic factors on build-up of citrus psylla, Diaphorina citri Kuwayama population in Punjab, India. Journal of Applied and Natural Science, 6(2): 371376.

Dharajothi, B., Vergheses, A. and Tandon, P.L. 1989. Ecological studies on citrus psylla, Diaphorina citri Kuwayama (Hemiptera: Psyllidae) with special reference to its spatial distribution and sampling plan. Entomon, 14(3-4): 319324.

Farmanullah, Badshah, H. and Gul, R. 2005. Evaluation of six different groups of insecticides for the control of citrus psylla, Diaphorina citri (Hemiptera: Psyllidae). Songklanakarin Journal of Science and Technology, 27(1): 17-23.

French, J. V., Kahlke C. J. and Graça J. V. DA 2001. First record of the Asian citrus psylla, Diaphorina citri Kuwayama (Homoptera: Psyllidae), in Texas. Subtropical Plant Science, 53: 14-15.

Fung, Y.C. and Chen, C.N. 2006. Effects of temperature and host plant on population parameters of the citrus psyllid (Diaphorina citri Kuwayama). Formosan Entomology, 26: 109-123.

Gravena S., Beretta M. J.G., Paiva P. E. B, Gallão R, and Yamamoto, P. T. 1996. Seasonal abundance and natural enemies of Diaphorina citri (Hemiptera: Psyllidae) in citrus orchards of São Paulo State, Brazil. p. 414. In: J V da Graça, P Moreno, and R K Yokomi (eds.), Proc 13th (IOCV). University of California, Riverside. 
Gravena, S. 2005. Practical Handbook of Ecological Management of Citrus Pest. Gravena, Jaboticabal, SP, Brazil.

Gupta, D., and Bhatia, R. 2000. Population dynamics of the citrus psylla, Diaphorina citri Kuwayama, in lower hills of Himachal Pradesh. Pest Management and Economic Zoology, 8(1): 41-45.

Halbert, S. E. and Manjunath, K. L. 2004. Asian citrus psyllids (Sternorryncha: Psyllidae) and greening disease of citrus: a literature review and assessment of risk in Florida. Florida Entomologist, 87: 330-53.

Halbert, S. E. and Nunez, C. A.2004. Distribution of the Asian citrus psyllid, Diaphorina citri Kuwayama (Rhynchota: Psyllidae) in the Caribbean basin. Florida Entomology, 87: 401402.

Hall, D.G., Hentz, M.G. and Adair, R.C. 2008. Population ecology and phenology of Diaphorina citri (Hemiptera: psyllidae) in two Florida citrus groves. Environmental Entomology, 37(4): 914-924.

Husain, M.A. and Nath, D. 1927. The citrus psylla (Diaphorina citri, Kuw.) [Psyllidae: Homoptera]. Memoirs of the Department of Agriculture in India. Entomological Series, 10(2): 5-27.

Jayanthimala, B.R., Pratheepa, M., Verghese, A., Tripathi, P.C., Ranaganath, H.R. and Sanganal, S. 2015. Role of climatic factors on citrus psylla, Diaphorina citri Kuwayama (Psyllidae: Hemiptera) in Coorg mandarin, Citrus reticulata Blanco. Current Biotica, 9(1):45-53.

Juan-Blasco M, Qureshi J. A, Urbaneja, A. and Stansly, P. A. 2012. predatory mite, amblyseius swirskii (acari: phytoseiidae), for biological control of asian citrus psyllid, Diaphorina citri (hemiptera: psyllidae). Florida Entomologist, 95: 543-51.
Kalita, H. and Baruah, B.P. 2001. Population build-up of certain pests in relation to weather factors. Journal of Applied Zoological Researches, 12(1): 51-52.

Khan, K.M., Radke, S.G. and Borle, M.N. 1989. Studies on the biology of citrus psylla. Diaphorina citri Kuwayama in the Vidarbha Region. Bulletin of Entomological Research, 30(1): 1-6.

Lakra, R. K., Singh, Z. and Kharub, W. S 1983. Population dynamics of citrus psylla, Diaphorina citri Kuwayama in Haryana. Indian Journal of Entomology, 45: 301-10.

Liu, Y.H. and Tsai, J.H. 2000. Effects of temperature on biology and life table parameters of the Asian citrus psyllid, Diaphorina citri Kuwayama. Annals of Applied Biology, 137 (3): 201-206.

Mangat, B.S. 1966. Biology and control of citrus psylla (Diaphorina citri Kuw.). Plant Protection Bulletin, 18(3): 18-20.

Martinez, A.L. and Wallence, J.M. 1967. Citrus leaf-mottle-yellows disease in the Philippines and transmission of the causal virus by a psyllid, Diaphorina citri. Plant Disease Report, 51 :692695.

McFarland, C.D. and Marjorie, A.H. 2001. Survival of Diaphorina citri (Homoptera: Psyllidae), and its two parasitoids, Tamarixia radiate (Hymenoptera: Eulophidae) and Diaphorencyrtus aligarhensis (Hymenoptera: Encyrtidae), under different relative humidities and temperature regimes. Florida Entomologist, 84(2): 227-233.

Mead, F. W. 1997. Asiatic citrus psyllid, Diaphorina citri Kuwayama. EENY-33. UF/IFAS Featured Creatures. EENY33. http://creatures.ifas.ufl.edu/citrus/ acpsyllid.htm.

Michaud, J. P. 2002. Biological control of Asian citrus psyllid, Diaphorina citri (Homoptera: Psyllidae), in Florida: a 
preliminary report. Entomological News, 113: 216-22.

Michaud, J. P. 2004. Natural mortality of Asian citrus psyllid (Homoptera: Psyllidae) in Central Florida. Biological Control, 29: 260-69.

Michaud, J.P. and Olsen, L. E. 2004. Suitability of Asian citrus psyllid, Diaphorina citri, as prey or ladybeetles. Biological Control, 49: 417-31.

Mizuno, T., Yoneda, M., Mizuniwa S. I., Dohino, T. 2004. Studies on cold hardiness and fecundity of the Asian citrus psylla, Diaphorina citri Kuwayama (Homoptera: Psyllidae) possibility of over-wintering of the Asian citrus psylla in the southern part of Kyushu. Research Bulletin of Plant Protection Japan, 40: 89-93.

Nava, D.E., Torres, M.L.G, Rodrigues, M.D.L., Bento, J.M.S. and Para, J.R.P. 2007. Biology of Diaphorina citri (Hemiptera: Psyllidae) on different hosts and at different temperatures. Journal of Applied Entomology, 131: 709-715.

Nehru, R.K., Bhagat, K.C. and Koul, V.K. 2006. Biology of Diaphorina citri Kuwayama on Citrus sinensis Osbeck. Environment and Ecology, 24(S): 443448.

Paiva Paulo, E. B. and Parra Jose, R. P. 2012. Life table analysis of Diaphorina citri (Hemiptera: Psyllidae) infesting sweet orange (Citrus sinensis) in São Paulo. Florida Entomologist, 95: 278-84.

Pande, Y.D. 1971. Biology of citrus psylla, Diaphorina citri Kuw. (Hemiptera:

Psyllidae). Israel Journal of Entomology, 6(2): 307-311.

Pluke, R. W. H., Qureshi, J. A. and Stansly, P. A. 2008. Citrus flushing patterns, Diaphorina citri (Homoptera: Psyllidae) populations and parasitism by Tamarixia radiata (Hymenoptera:
Eulophidae) in Puerto Rico. Florida Entomologist, 91: 36-41.

Pruthi, H.S. 1969. Text book of agricultural entomology Indian Council of Agricultural Research, New Delhi. pp. 977.

Pruthi, H.S. and Mani, M.S. 1945. Our knowledge of the insect and mine pests of the citrus in India and their control. Imperial Council Agricultural Research Sciences Monograph.16: 1-42.

Quasim, M. and Hussain, D. 2015. Efficacy of insecticides against citrus psylla in field and laboratory conditions. Cercetări Agronomice in Moldova, 162(2): 91-97.

Qureshi J. A., Rogers M. E., Hall D. G. and Stansly P. A.2009. Incidence of invasive Diaphorina citri (Hemiptera: Psyllidae) and its introduced parasitoid Tamarixia radiata (Hymenoptera: Eulophidae) in Florida citrus. Journal of economic Entomology, 102: 247-56.

Qureshi, J.A., Stansly, P.A. 2007. Integrated approaches for managing the Asian citrus psyllid Diaphorina citri (Homoptera: Psyllidae) in Florida. Proceeding of Florida State Horticulture Society, 120:110-15.

Radke, S.G., Ghuguskar, H.T. and Borle, M.N., 1981. Chemical control of the adult citrus psylla Diaphorina citri Kuwayama. Punjabrao Krishi Vidyapeeth Research Journal, 5:148150.

Rakshnani, E. and Saeedifar, A. 2013. Seasonal fluctuations, spatial distribution and natural enemies of Asian citrus psyllid, Diaphorina citri Kuwayama (Hemiptera: Psyllidae) in Iran. Entomological Science, 16: 17-25.

Randhava, G.S. 1974. Horticulture Importance of pest control. Pesticides Annual. 8: 85-87.

Rao, C. and Shivankar, V. 2011. Relative efficacy of certain bio-rational 
insecticides to citrus psylla, $D$. citri. Indian Journal of Agricultural Sciences, 81(7):673-676.

Sahu, S.R. and Mandal, S.K. 1997. Population fluctuation of citrus psylla, Diaphorina citriKuwayama. Journal ofInteracademica, 1:329-332.

Salibe, A.A. and Cotrez, R.E. 1966. Studies on the leaf mottling disease of citrus in the Philippines. FAD Plant Protection Bulletin., 14:141-144.

Sarada, G., Gopal K., Nagalaxmi, T., Venkatramna, K.T., Mukundalaxmi, L., Gourishankar, T. and Gopi, V. 2014. Management of citrus psylla (Diaphorina citri Kuwayama) using bio rational insecticides. Journal of Ecology and Environmental Sciences, 3 (2): 911.

Setamou M., Rodriguez, D., Saldana, R., Schwarzlose, G., Palrang, D., Nelson, S.D. 2010. Efficacy and uptake of soilapplied imidacloprid in the control of Asian citrus psyllid and a citrus leafminer, two foliar-feeding citrus pests. Journal of Economic Entomology, 103(5):1711-19.

Sharma, D.R. 2008. Population dynamics in relation to abiotic factors and management of citrus psylla in Punjab. Indian Journal of Horticulture, 65(4):417-422.

Shivankar, V.J. and Rao, C.N. 2005. Final Report on Integrated management of citrus psylla (Diaphorina citri Kuwayama). N.R.C. for Citrus, Nagpur.

Singh T, Singh B, Singh T and Singh B., 1990. Incidence and seasonal abundance of citrus psylla, Diaphorina citri (Kuwayama) on the Citrus spp. grown in some districts of Punjab. Indian Journal of Entomology, 52: 13945.

Singh, G. 1963. Studies on the biology and control of Diaphorina citri Kuw. M.Sc. (Agri.) Thesis. Agra University, India.
Singh, N.V. 2017. Bio-ecology and chemical control of citrus psylla, Diaphorina citri, Kuwayama on sweet orange. Ph.D. Thesis, CCS HAU, Hisar.

Skelley, L.H. and Hoy, M.A. 2004. A synchronous rearing method for the Asian citrus psyllid and its parasitoids in quarantine. Biological Control, 29: 14-23.

Sule, H. and Muhamad, R. 2014. Dynamics and distribution of Diaphorina citri (Hemiptera: Psyllidae) in a citrus orchard in Terengganu, Malaysia. Scientific Papers. Series A. Agronomy, 7: 461-465.

Tandon, P.L. 1992. In Compendium of Lectures of "Summer Institute on IPM in Horticultural Crops" held at IIHR, Bangalore, pp. 19-26.

Teck, S.L.C., Fatimah, A., Beattie, A., Heng, R.K.J. and King, W.S. 2011. Seasonal Population Dynamics of the Asian Citrus Psyllid, Diaphorina citri Kuwayama in Sarawak. American Journal of Agricultural and Biological Sciences, 6 (4): 527-535.

Tirtawidjaja S, Hadiwidjaja T, Lasheen AM. 1965. Citrus vein phloem degeneration virus, a possible cause of citrus chlorosis in Java. Proceedings of the American Society of Horticultural Science 86:235-243.

Tsai, J.H. and Liu, Y.H. 2000. Biology of Diaphorina citri (Homopteran: Psyllidae) on four host plants. Journal of Economic Entomology, 93(6): 17211725.

Tsai, J.H., Wang, Jin-Jun and Lui, Ying-hong 2002. Seasonal abundance of the Asian citrus psyllid, Diaphorina citri (Homoptera: Psyllidae) in Southern Florida. Florida Entomologist, 85(3):446-451.

Van den Berg MA, van Vuuren SP and Deacon VE. 1992. Studies on greening disease transmission by the citrus 
psylla, Trioza erytreae (Hemiptera: Triozidae). Israel Journal of Entomology, 25: 51-56.

Vetter, R. S., khan, S. Z., Arif, M. J., Hoddle, C. and Hoddle, M.S., 2013. Spiders (Araneae) surveyed from unsprayed citrus orchards in Faisalabad, Pakistan and their potential as biological control agents of Diaphorina citri (Hemiptera: Liviidae). Pakistan Entomology, 35: 6169.

Viraktamath, C.A. and Bhumannavar, B.S. 2002. Biology, ecology and management of Diaphorina citri Kuwayama (Hemiptera: psyllidae). Pest Management in Horticultural Ecosystems, 7(1): 1-27.

Wadhi, S.R. and Batra, H.N. 1964. Pests of tropical and sub-tropical fruit trees. In: Entomology in India 1938Đ1963. Silver Jubilee Number of the Indian Journal of Entomology., 247.

Wankhade, S.M., Kadam, U.K., Patil, S.K. and Bansode, G.M. 2015. Studies on the seasonal incidence and management of citrus psylla (Diaphorina citri Kuwayama) in sweet orange. Indian Journal of Agriculture Research, 49(4): 321-326.
Waterston J. 1922. On the chalcidoid parasites of psyllids (Hemiptera: Homoptera). Bulletin of Entomological Research, 13:41-58.

Wenningger, E.J. and Hall, D.G. 2007. Daily timing of mating and age at reproductive maturity in Diaphorina citri (Hemiptera: Psyllidae). Florida Entomologist, 90(4): 715-722.

Xu, C.F., Xia, Y.H. and Ke, C. 1994. A study on the biology and control of the citrus psylla. [Chinese]. Acta Phytophylacica Sinica, 21(1):53-56.

Yamamoto, P.T., Pavia, P.E.B. and Gravena, S. 2001. Population dynamics of Diaphorina citri Kuwayama (Hemiptera: psyllidae) in citrus orchards in the North of Sao Paulo State, Brazil. Neotropical Entomology, 30(1): 165170.

Yang Y, Huang M, Andrew G, Beattie C, Xia Y, Ouyang G and Xiong J. 2006. Distribution, biology, ecology and control of the psyllid Diaphorina citri Kuwayama, a major pest of citrus: A status report for China. International Journal of Pest Management, 52: 34352.

\section{How to cite this article:}

Naveen Vikram Singh and Yadav, G.S. 2018. Bio-ecology and Management of Citrus psylla, Diaphorina citri Kuwayama on Citrus - A Review. Int.J.Curr.Microbiol.App.Sci. 7(04): 30913107. doi: https://doi.org/10.20546/ijcmas.2018.704.351 